\title{
Cerebral Cortical Blood Flow and Oxygen Metabolism in Normocythemic Hyperviscous Newborn Piglets
}

\author{
MARSHALL GOLDSTEIN ${ }^{1}$ BARBARA S. STONESTREET, BENJAMIN S. BRANN IV, AND \\ WILLIAM OH \\ Department of Pediatrics, Women and Infants Hospital of Rhode Island and the Department of Pediatrics, \\ Brown University Program in Medicine, Providence, Rhode Island 02905
}

\begin{abstract}
Our study tests the hypothesis that hyperviscosity independent of arterial $\mathrm{O}_{2}$ content reduces cerebral cortical blood flow, $\mathrm{O}_{2}$ delivery, and $\mathrm{O}_{2}$ uptake. After baseline determinations, ten 2- to 4-day-old awake spontaneously breathing piglets.were given an intravenous infusion ( $5 \mathrm{ml} \cdot \mathrm{kg}^{-1}$, body weight) of concentrated cyroprecipitate, whereas eight controls received normal saline. Cerebral cortical blood flow, arterial and superior sagittal sinus $\mathrm{O}_{2}$ content, whole blood viscosity, hematocrit, blood gases, and plasma fibrinogen concentrations were measured at baseline and $3 \mathrm{~h}$ after infusion. No significant changes were observed in the control group. Three hours after the infusion of concentrated cryoprecipitate the experimental group showed an increase in whole blood viscosity, whereas hematocrit and arterial $\mathrm{O}_{2}$ content were unchanged. There was a decrease in cerebral cortical blood flow and cerebral cortical $\mathrm{O}_{2}$ delivery, whereas cerebral cortical $\mathrm{O}_{2}$ uptake was unchanged. We conclude that hyperviscosity independent of arterial $\mathrm{O}_{2}$ content reduces cerebral cortical blood flow and that although $\mathrm{O}_{2}$ delivery was reduced in the newborn piglet cerebral cortical $\mathbf{O}_{2}$ uptake was maintained. (Pediatr Res 24: 486-489, 1988)
\end{abstract}

Polycythemia and hyperviscosity occur in $3-5 \%$ of newborns $(1,2)$. Structural and functional CNS abnormalities have been associated with polycythemia and hyperviscosity (3-9). The most common etiology of neonatal hyperviscosity is polycythemia. However, approximately $1 \%$ of newborns have been reported to be hyperviscous with normal hematocrits $(1,2)$. Decreased deformability of the red blood cell $(10,11)$ or elevated concentrations of plasma proteins including fibrinogen and IgM are additional etiologies (12). Hyperfibrinogenemia has been associated with polycythemia in fetal lambs (13) and full-term newborns (14).

To investigate the association of polycythemia and hyperviscosity with CNS abnormalities, physiologic studies have been reported in adult and neonatal subjects delineating the effects of polycythemia and hyperviscosity on cerebral circulation and metabolism. An inverse relationship between polycythemia and

Received March 21, 1988; accepted June 14, 1988.

Correspondence and reprint requests William Oh, M.D., 101 Dudley Street, Providence, RI 02905-2401.

Supported in part by Public Health Service Award Grant 1 T32-HD-07232-03, National Institute of Child Health and Human Development, and the National Institute of Child Health and Human Development Diabetes Center Grant HD11343, Bethesda, MD.

1 Present address Children's Hospital of Buffalo, Department of Pediatrics, 219 Bryant Street, Buffalo, NY 14222. cerebral blood flow has been demonstrated in adults with primary polycythemia (15-17). In the neonate, polycythemia is associated with decreased cerebral blood flow velocity and increased pulsatility indices that are reversed by partial plasma exchange transfusion $(18,19)$. However, Jones et al. (20) emphasized the importance of arterial $\mathrm{O}_{2}$ content in the regulation of cerebral blood flow. To maintain a constant $\mathrm{O}_{2}$ delivery, an alteration in arterial $\mathrm{O}_{2}$ content results in a reciprocal change in blood flow. Rosenkrantz et al. (21) showed in newborn lambs that the cerebral blood flow reduction noted with polycythemic hyperviscosity is due to the increased arterial $\mathrm{O}_{2}$ content from polycythemia and not the result of hyperviscosity. Nevertheless, in paraproteinemic adults Humphrey and coworkers $(22,23)$, demonstrated that $\mathrm{O}_{2}$ content and blood viscosity are both independent variables controlling cerebral blood flow.

To examine the effect of hyperviscosity independent of polycythemia and arterial $\mathrm{O}_{2}$ content, a normocythemic hyperviscous animal model was developed. This study is designed to test the hypothesis that normocythemic hyperviscosity reduces cerebral cortical blood flow, $\mathrm{O}_{2}$ delivery, and $\mathrm{O}_{2}$ uptake in newborn piglets.

\section{MATERIALS AND METHODS}

Animals. Eighteen newborn piglets were randomly divided into experimental $(n=10)$ and control $(n=8)$ groups and studied between 2 and 4 days of age. Animal weights on the day of study were $1290 \pm 207 \mathrm{~g}$ (mean \pm SD) and $1280 \pm 158 \mathrm{~g}$ for the experimental and control piglets, respectively.

Animal preparation. Catheters were surgically placed under sterile conditions 18 hours prior to the study using $70 \%$ nitrous oxide and $30 \%$ oxygen analgesia administered via a head hood and $1 \%$ lidocaine local anesthesia. Catheters were placed into the: 1) left ventricle via the left carotid artery, verified by blood pressure tracing, for microsphere injection, 2) midthoracic aorta via the right femoral artery, for microsphere reference and arterial blood sampling as listed below, 3) abdominal aorta via the left femoral artery, for blood pressure and heart rate recording, 4) inferior vena cava via a femoral vein, for cryoprecipitate or normal saline administration, and 5) superior sagittal sinus, for cerebral cortical efferent blood sampling.

Postoperatively, the piglets received parenteral ampicillin $(100$ $\left.\mathrm{mg} \cdot \mathrm{kg}^{-1}\right)$, kanamycin $\left(5 \mathrm{mg} \cdot \mathrm{kg}^{-1}\right)$, and $\mathrm{D}_{5} \mathrm{~W}\left(10 \mathrm{ml} \cdot \mathrm{kg}^{-1}\right)$. All catheters were filled with heparin $\left(1000 \mathrm{U} \cdot \mathrm{ml}^{-1}\right)$, closed, and secured to the flank. After recovery from anesthesia, the piglets were gavage fed $\left(30 \mathrm{ml} \cdot \mathrm{kg}^{-1}\right)$ every $3 \mathrm{~h}$, until $8 \mathrm{~h}$ before the onset of the study, with an artificial pig milk preparation (Land-OLakes, Inc., Minneapolis, MN). The piglets remained warm and unrestrained during the overnite recovery and throughout the study period in a small cushioned animal plastic cage. 
Experimental protocol. After 18-24 h of recovery from surgery, baseline measurements were made at time 0 . Immediately thereafter, $5 \mathrm{ml} \cdot \mathrm{kg}^{-1}$ of fibrinogen containing concentrated cryoprecipitate were intravenously administered over $10 \mathrm{~min}$ to the experimental and normal saline to the control piglets. A second determination was made after a 3-h interval. Each determination included: arterial whole blood viscosity, hematocrit, blood gases, and plasma fibrinogen; arterial and superior sagittal sinus $\mathrm{O}_{2}$ content; and cerebral cortical blood flow. Hematocrits were maintained during the study by replacement with whole blood obtained from donor piglets of comparable age to the study animals.

At the conclusion of the study, the piglets were killed with an overdose of sodium thiamylal followed by $\mathrm{KCl}$ given via the left ventricular catheter. Placement of all catheters was verified at autopsy. The cerebral cortex, kidneys, and lungs were weighed and prepared as previously described (24).

Methodology. Concentrated cryoprecipitate was prepared $24 \mathrm{~h}$ before the study as follows. Fresh human cryoprecipitate kept frozen at $-18^{\circ} \mathrm{C}$ was then placed in a $4^{\circ} \mathrm{C}$ refrigerator. A total of $5 \mathrm{U}$ of cryoprecipitate was pooled and centrifuged at $5000 \times$ $g$ for $5 \mathrm{~min}$. This procedure increased the cryoprecipitate fibrinogen concentration from $266 \pm 98 \mathrm{mg} \cdot 100 \mathrm{ml}^{-1}$ to $594 \pm 216$ $\mathrm{mg} \cdot 100 \mathrm{ml}^{-1}$.

Preliminary in vitro experiments on newborn piglet whole blood showed that a 20:1 ratio of blood to concentrated cryoprecipitate resulted in a significant elevation of viscosity. Assuming a blood volume of 90 to $100 \mathrm{ml} \cdot \mathrm{kg}^{-1}$, body weight (25), we anticipated that a $5 \mathrm{ml} \cdot \mathrm{kg}^{-1}$ infusion of concentrated cryoprecipitate would produce the desired hyperviscosity in vivo. Hyperviscosity was defined as a whole blood viscosity greater than $2 \mathrm{SD}$ above the mean $(1,2)$ in this breed of newborn piglets.

Blood pressure and heart rate were monitored with a PB1280 Hewlett Packard pressure transducer and recorded on a Hewlett Packard polygraph 7754A series (Hewlett Packard, Lexington, MA). Hematocrit was measured in triplicate by the microhematocrit method. Whole blood viscosity was determined with duplicate $0.5 \mathrm{ml}$ heparinized samples at a shear rate of $11.25 \cdot \mathrm{s}^{-1}$ with a Wells-Brookfield micro-viscometer LVT-CP at a constant temperature $\left(37^{\circ} \mathrm{C}\right)$ (Brookfield Engineering Laboratories, Stoughton, MA). Blood was analyzed immediately after sampling to minimize any erythrocyte settling. Blood gases were determined on a Corning Blood Gas Analyzer 175 (Corning Scientific Instruments, Medford, MA). Oxygen contents were done in duplicate with the Lex- $\mathrm{O}_{2}$-Con (Lexington Instruments Corp., Waltham, MA). Plasma fibrinogen concentration was determined in duplicate using a coagulation assay (Ortho Diagnostic Systems, Inc., Raritan, NJ) adapted from the method of Clauss (26). Serum osmolality was determined with a vapor pressure osmometer (Wescor, Inc., Logan, UT).

Blood flow determinations were measured by the radionuclidelabeled microsphere technique (24). Microspheres of $15 \pm 5 \mu$ in diameter labeled with ${ }^{113} \mathrm{Sn},{ }^{46} \mathrm{Sc},{ }^{95} \mathrm{Nb},{ }^{57} \mathrm{Co},{ }^{51} \mathrm{Cr}$, or ${ }^{103} \mathrm{Ru}$ were used (New England Nuclear, Inc., Boston, MA). A total of $9 \times$ $10^{5}$ microspheres suspended in $2.0 \mathrm{ml} 10 \%$ dextran and $0.01 \%$ Tween was continuously mixed, injected into the left ventricle over a 30-s period, and then flushed with $2.0 \mathrm{ml}$ of normal saline. Beginning $15 \mathrm{~s}$ before injection, the reference blood sample was withdrawn from the midthoracic aortic catheter at $1.03 \mathrm{ml}$. $\mathrm{min}^{-1}$ for 2 min into glass syringes by a constant withdrawal pump (Harvard Apparatus, Millis, MA). Blood pressure and heart rate were monitored continuously. The radioactivity of all tissue and blood samples was measured in a gamma well counter [(Tracor Analytic Model 1185, Elk Grove Village, IL) connected with a multichannel pulse-height analyzer (Canberra model 4203, Meriden, CT)]. All tissue and blood samples contained sufficient microspheres to insure accuracy to within \pm 5 to $10 \%$ (24). Shunting through a patent ductus arteriosus was excluded by measurement of pulmonary counts. Microsphere streaming was excluded by equivalent blood flow to both kidneys and cerebral cortical hemispheres (data not shown). Blood flow data was generated with a Digital PdP-11/34 computer (Digital Equipment Corp., Maynard, MA) as previously described (27).

Data analysis. Formulas used for calculations are as follows:

$$
\mathrm{O}_{2} \text { delivery }=\text { blood flow } \times \text { arterial } \mathrm{O}_{2} \text { content }
$$

$$
\begin{aligned}
& \text { fractional } \mathrm{O}_{2} \text { extraction }=\frac{(\text { arterial-venous }) \mathrm{O}_{2} \text { content }}{\text { arterial } \mathrm{O}_{2} \text { content }} \\
& \mathrm{O}_{2} \text { uptake }=\text { blood flow } \times(\text { arterial-venous }) \mathrm{O}_{2} \text { content }
\end{aligned}
$$

Statistical analysis was performed by paired and unpaired $t$ tests with the Bonferroni correction for intragroup and intergroup analysis, respectively (28). Statistical significance was designated at $p<0.01$. All values are expressed as mean $\pm \mathrm{SD}$.

\section{RESULTS}

The increase in whole blood viscosity in the experimental piglets at the $11.25 \cdot \mathrm{s}^{-1}$ shear rate $3 \mathrm{~h}$ after cryoprecipitate administration is documented in Figure 1 . The viscosity value was more than 2 SD above the experimental baseline and control group values. Arterial $\mathrm{O}_{2}$ contents were unchanged in both groups during the study. Plasma fibrinogen concentrations in the experimental group increased from a baseline $135 \pm 62$ to 180 $\pm 59 \mathrm{mg} \cdot 100 \mathrm{ml}^{-1}$ at $3 \mathrm{~h}(p<0.001)$, whereas no change was observed in the control group. No change in serum osmolality was observed. Experimental piglets $(n=7)$ had a baseline of 278 \pm 7 and a $3-\mathrm{h}$ value of $276 \pm 8 \mathrm{mosmol} / \mathrm{kg}$, whereas controls $(n$ $=5$ ) had a baseline of $280 \pm 13$ and a 3-h determination of 275 $\pm 18 \mathrm{mosmol} / \mathrm{kg}$.

A summary of the hemodynamic, hematocrit, and blood gas data is shown in Table 1. Significant changes were not observed. Superior sagittal sinus pressures were unchanged: a baseline of 3 \pm 2 and 3 -h value of $4 \pm 2 \mathrm{~mm} \mathrm{Hg}$ in experimentals $(n=6)$, and a baseline of $3 \pm 2$ and $3-\mathrm{h}$ value of $2 \pm 1 \mathrm{~mm} \mathrm{Hg}$ in controls $(n=5)$.

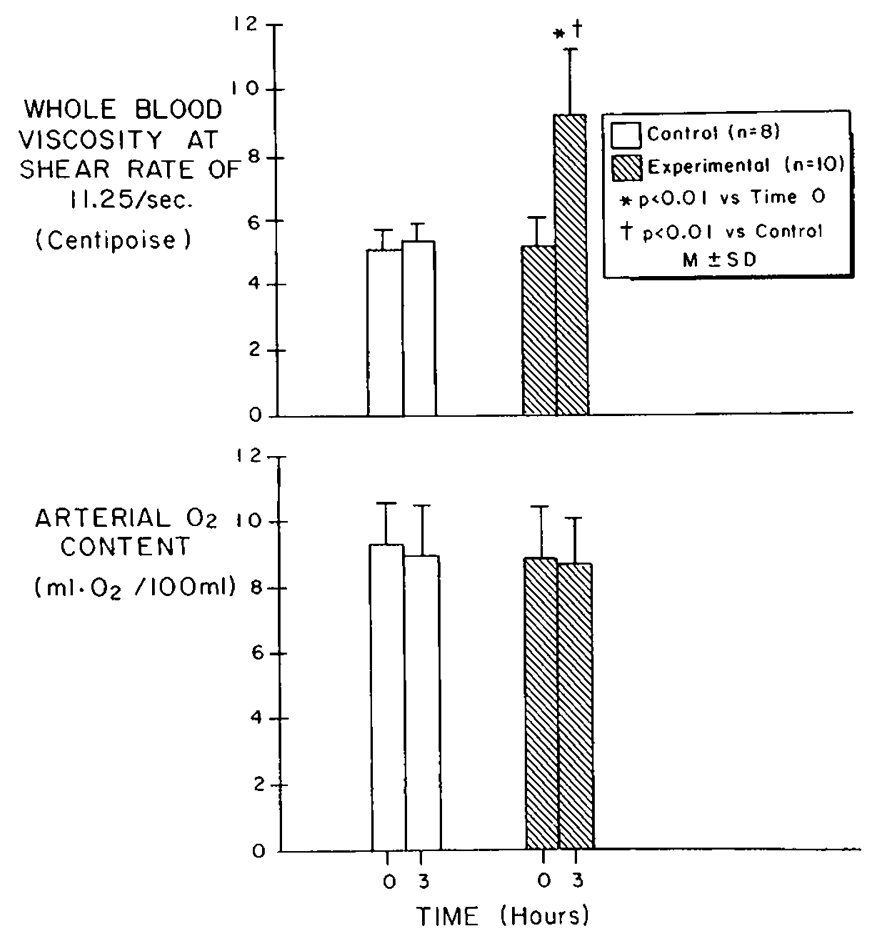

Fig. 1. Whole blood viscosity at a shear rate of $11.25 \cdot \mathrm{s}^{-1}$ and arterial $\mathrm{O}_{2}$ content plotted against time in hours of the study protocol for the control and experimental groups. 
Table 2 shows the cerebral cortical blood flow and $\mathrm{O}_{2}$ metabolism data. Cerebral cortical blood flow and $\mathrm{O}_{2}$ delivery were decreased in the hyperviscous piglets at $3 \mathrm{~h}$ compared to baseline. No significant changes in cerebral cortical fractional $\mathrm{O}_{2}$ extraction or $\mathrm{O}_{2}$ uptake were observed.

\section{DISCUSSION}

Normocythemic hyperviscosity in the newborn piglet results in decreased cerebral cortical blood flow and thereby $\mathrm{O}_{2}$ delivery although $\mathrm{O}_{2}$ uptake was preserved. By inducing hyperviscosity with a fibrinogen-rich infusion, hematocrit and arterial $\mathrm{O}_{2}$ content are maintained constant. Therefore, the reductions in cerebral cortical blood flow and $\mathrm{O}_{2}$-delivery are consistent with an independent effect of hyperviscosity.

Fibrinogen, an anisometric plasma protein, increases whole blood viscosity predominantly at low shear rates by enhancing erythrocyte aggregation (29). The shear rate of $11.25 \cdot \mathrm{s}^{-1}$, used for data analysis in our study, is within the range that Wells et al. (31) documented an in vitro increase in blood viscosity as fibrinogen concentration increases (30). This shear rate approximates that of the small arterioles and venules (31). By in vitro viscosity measurement, the viscosity increase induced in this study in newborn piglets approximates that in the human newborn as the hematocrit increases from 40 to $55 \%$ (8).

A possible variable in our study is if the infusion of concentrated human cryoprecipitate had a significant vasoactive effect on the newborn piglet. Although we cannot exclude the presence of such substances, we suggest that major vasoactive substances were not present as changes in heart rate and blood pressure were not observed.

Our findings of a reduced cerebral cortical blood flow during hyperviscosity supports previous studies with polycythemic newborns $(18,19)$ and adults $(15-17)$, and paraproteinemic hyperviscous adults $(22,23)$. Our data are also consistent with the newborn lamb model of Hudak et al. (32) in which the independent effect of hematocrit on cerebral cortical blood flow was investigated. In that experiment, isovolemic exchange transfusion of methemoglobinemic erythrocytes resulted in polycythemic hyperviscosity with only a small increase in arterial $\mathrm{O}_{2}$

Table 1. Hemodynamic, hematocrit, and blood gas values (mean $\pm S D)$

\begin{tabular}{|c|c|c|c|c|}
\hline & \multicolumn{2}{|c|}{ Experimental $(n=10)$} & \multicolumn{2}{|c|}{ Control $(n=8)$} \\
\hline & $0 \mathrm{~h}$ & $3 \mathrm{~h}$ & $0 \mathrm{~h}$ & $3 \mathrm{~h}$ \\
\hline $\begin{array}{l}\text { Heart rate (beats. } \\
\min ^{-1} \text { ) }\end{array}$ & $217 \pm 35$ & $190 \pm 33$ & $212 \pm 21$ & $224 \pm 26$ \\
\hline $\begin{array}{l}\text { Mean arterial blood } \\
\text { pressure }(\mathrm{mm} \mathrm{Hg})\end{array}$ & $65 \pm 13$ & $66 \pm 13$ & $71 \pm 12$ & $68 \pm 10$ \\
\hline Hematocrit (\%) & $23 \pm 4$ & $23 \pm 4$ & $23 \pm 3$ & $23 \pm 3$ \\
\hline $\mathrm{pH}$ & $7.48 \pm 0.04$ & $7.48 \pm 0.02$ & $7.48 \pm 0.04$ & $7.50 \pm 0.03$ \\
\hline $\mathrm{PaO}_{2}(\mathrm{~mm} \mathrm{Hg})$ & $86 \pm 16$ & $84 \pm 9$ & $83 \pm 8$ & $82 \pm 7$ \\
\hline $\mathrm{PaCO}_{2}(\mathrm{~mm} \mathrm{Hg})$ & $41 \pm 2$ & $41 \pm 5$ & $43 \pm 3$ & $41 \pm 3$ \\
\hline $\begin{array}{l}\text { Base excess (mM } \\
\left.\quad \cdot \text { liter }^{-1}\right)\end{array}$ & $7 \pm 2$ & $7 \pm 2$ & $9 \pm 3$ & $9 \pm 3$ \\
\hline
\end{tabular}

content. A reduction in cerebral cortical blood flow comparable to that noted in our study and maintenance of $\mathrm{O}_{2}$ uptake were observed. Hudak et al. (32) concluded that the red blood cell concentration by viscous and or nonviscous-mediated mechanisms affected cerebral blood flow.

Our data appear to contradict the findings in a previous report of a polycythemic hyperviscous lamb model (21). The reduction in cerebral blood flow was determined by Rosenkrantz et al. (21) to be a response to an increase in arterial $\mathrm{O}_{2}$ content and not related to an increased blood viscosity. However, in that study, the intravenous infusion of sodium nitrite, used to induce methemoglobinemia, may have also altered erythrocyte $\mathrm{O}_{2}$ affinity (33).

The importance of arterial $\mathrm{O}_{2}$ content in cerebral cortical blood flow regulation has been previously established $(20,34)$. However, the results of our study and that of Hudak et al. (32) suggest that changes in whole blood viscosity, by an increase in fibrinogen or an expansion of red cell mass, respectively, represent an independent variable in the control of cerebral circulation in the newborn.

Although cerebral cortical $\mathrm{O}_{2}$ delivery was reduced in our hyperviscous piglets, a significant increase in $\mathrm{O}_{2}$ extraction was not observed. This is likely the result of intersubject variability. Cerebral cortical fractional $\mathrm{O}_{2}$ extraction in our piglets is in the range reported by Jones et al. (20).

In summary, hyperfibrinogenemic normocythemic hyperviscosity in the newborn piglet results in a reduction in cerebral cortical blood flow and $\mathrm{O}_{2}$ delivery insufficient to compromise cortical $\mathrm{O}_{2}$ uptake.

Acknowledgment. The authors thank Mrs. Donna Piva for her excellent technical assistance.

\section{REFERENCES}

1. Stevens K, Wirth FH 1980 Incidence of neonatal hyperviscosity at sea level. J Pediatr 97:118-119

2. Wirth FH, Goldberg KE, Lubchenco LO 1979 Neonatal hyperviscosity: I Incidence. Pediatrics 63:833-836

3. Wood JL 1959 Plethora in the newborn infant associated with cyanosis and convulsions. J Pediatr 54:143-151

4. Black VD, Lubchenco LO, Luckey DW, Koops BL, McGuinness GA, Powell DP, Tomlinson AL 1982 Developmental and neurologic sequelae of neonatal hyperviscosity syndrome. Pediatrics 69:426-431

5. Amit M, Camfield PR 1980 Neonatal polycythemia causing multiple cerebral infarcts. Arch Neurol 37:109-110

6. Miller GM, Black VD, Lubchenco LO 1981 Intracerebral hemorrhage in a term newborn with hyperviscosity. Am J Dis Child 135:377-378

7. Koffler H, Keenan WJ, Sutherland JM 1974 Hydranencephaly following elevated hematocrit values in a newly born infant. Pediatrics 54:770-772

8. Gross GP, Hathaway WE, McGaughey HR 1973 Hyperviscosity in the neonate. J Pediatr 82:1004-1012

9. Goldberg K, Wirth FH, Hathaway WE, Guggenheim MA, Murphy JR, Braith waite WR, Lubchenco LO 1982 Neonatal hyperviscosity II. Effect of partia plasma exchange transfusion. Pediatrics 69:419-425

10. Bergqvist G 1974 Viscosity of the blood in the newborn infant. Acta Paediatr Scand 63:858-864

11. Gross GP, Hathaway WE 1972 Fetal erythrocyte deformability. Pediatr Res 6:593-599

12. Wells R 1970 Syndromes of hyperviscosity. N Engl J Med 283:183-186

13. Pickart LR, Creasy RK, Thaler MM 1976 Hyperfibrinogenemia and polycythemia with intrauterine growth retardation in fetal lambs. Am $\mathbf{J}$ Obstet Gynecol 124:268-271

Table 2. Cerebral cortical (CC) blood flow, $\mathrm{O}_{2}$ delivery, $\mathrm{O}_{2}$ fractional extraction, and $\mathrm{O}_{2}$ uptake (mean $\left.\pm S D\right)$

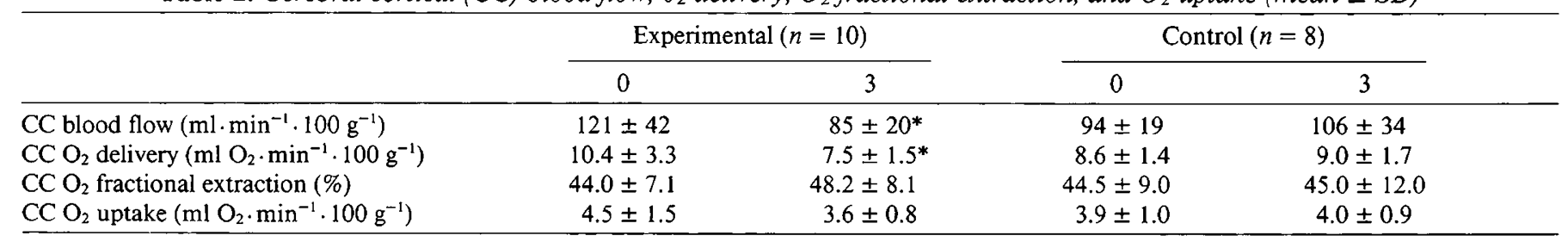

\footnotetext{
$* p<0.01$ versus time 0 .
} 
14. Pickart LR, Creasy RK, Thaler MM 1976 Hyperfibrinogenemia in polycythemic newborns and growth-retarded fetuses. Pediatr Res 10:380(abstr)

15. Humphrey PRD, DuBoulay GH, Marshall J, Pearson TC, Ross Russell RW, Symon L, Wetherley-Mein G, Zilkha E 1979 Cerebral blood-flow and viscosity in relative polycythaemia. Lancet 2:873-877

16. Thomas DJ, DuBoulay GH, Marshall J, Pearson TC, Ross Russell RW, Symon L, Wetherley-Mein G, Zilkha E 1977 Effect of haematocrit on cerebral blood-flow in man. Lancet 2:941-943

17. Thomas DJ, DuBoulay GH, Marshall J, Pearson TC, Ross Russell RW, Symon L, Wetherley-Mein G, Zilkha E 1977 Cerebral blood-flow in polycythaemia. Lancet 2:161-163

18. Kolni HW, Bada HS, Korones SB, Fitch CW, Ford DL 1982 Cerebral arterial pulsatile flow changes in neonatal polycythemia and hyperviscosity. Pediatr Res 16:295(abstr)

19. Rosenkrantz TS, Oh W 1982 Cerebral blood flow velocity in infants with polycythemia and hyperviscosity: effects of partial exchange transfusion with plasmanate. J Pediatr 101:94-98

20. Jones MD Jr, Traystman RJ, Simmons MA, Molteni RA 1981 Effects of changes in arterial $\mathrm{O}_{2}$ content on cerebral blood flow in the lamb. Am $J$ Physiol 240:H209-H215

21. Rosenkrantz TS, Stonestreet BS, Hansen NB, Nowicki P, Oh W 1984 Cerebral blood flow in the newborn lamb with polycythemia and hyperviscosity. $J$ Pediatr 104:276-280

22. Humphrey PRD, DuBoulay GH, Marshall J, Pearston TC, Ross Russell RW, Slater NGP, Symon L, Wetherly-Mein G, Zilkha E 1980 Viscosity, cerebral blood flow and haematocrit in patients with paraproteinaemia. Acta Neurol Scand 61:201-209

23. Humphrey PRD 1981 Changes in cerebral blood flow relating to haemotocrit and viscosity. Scand J Clin Lab Invest [Suppl] 156:209-211

24. Heymann MA, Payne BD, Hoffman JIE, Rudolph AM 1977 Blood flow measurements with radionuclide-labeled particles. Prog Cardiovasc Dis 20:55-79

25. Pond WG, Houpt KA 1978 Body fluids, hematology, and immunology. In: Pond WE, Houpt KA (eds). The Biology of the Pig. Cornell University Press, Ithaca, NY, pp 247-258

26. Clauss A 1957 Rapid physiological coagulation method for the determination of fibrinogen. Acta Haematol 17:237-246

27. Nowicki PT, Oh W, Yao A, Hansen NB, Stonestreet BS 1984 Effect of polycythemia on gastrointestinal blood flow and oxygenation in piglets. Am J Physiol 247:G220-G225

28. Wallenstein S, Zucker CL, Fleiss JL 1980 Some statistical methods useful in circulation research. Circ Res 47:1-9

29. Merrill EW 1969 Rheology of blood. Physiol Rev 49:863-887

30. Wells RE Jr, Gawronski TH, Cox PJ, Perera RD 1964 Influence of fibrinogen on flow properties of erythrocyte suspensions. Am J Physiol 207:1035-1040

31. Oski FA, Naiman JL 1982 Polycythemia and hyperviscosity in the neonatal period. In: Oski FA, Naiman JL (eds). Hematologic Problems in the Newborn. WB Saunders Company, Philadelphia, pp 87-96

32. Hudak ML, Koehler RC, Rosenberg AA, Traystman RJ, Jones MD Jr 1986 Effect of hematocrit on cerebral blood flow. Am J Physiol 251:H63-H70

33. Roughton FJW 1964 Transport of oxygen and carbon dioxide. In: Handbook for Physiology. Respiration. American Physiology Society, Washington, DC, pp 767-826

34. Brown MM, Wade JPH, Marshall J 1985 Fundamental importance of arterial oxygen content in the regulation of cerebral blood flow in man. Brain 108:81-93 